\title{
INVESTMENT SUBSIDIES IN THE MEAT INDUSTRY AND THEIR IMPACT ON BUSINESS ECONOMICS
}

\author{
Náglová, Z.
}

This article deals with meat industry subsidies in the Czech Republic. Food processing businesses are entitled to draw funds from the Rural Development Program 2007-2013 (RDP), Axis I, Measure I. 1. 3 Adding value to agricultural and food products. The aim of this paper is to assess whether there were any changes in performance indicators in subsidized meat businesses and to identify their effects on the meat industry. Competitiveness of meat industry is low. Subsidies are among other factors that can help to reach for better competitiveness of this branch. The fixed effect model was used in order to carry out the analysis. According to the results, subsidized meat enterprises did not display any increase in business performance (no increase in labour productivity, value added growth in the supported firm were found) and cannot be considered as a key factor of competitiveness. There was a positive impact on the number of employees and the value of fixed assets in the year the subsidies were drawn. However, the effective use of workers and property did not reflect other performance indicators in the year of drawing.

Keywords: rural development program; subsidy; meat industry; business economy; fixed effect model

JEL classification: L66, M21, B23

\section{Introduction}

The meat industry in the Czech Republic was selected due to its importance within the Czech food industry. It has significant in participation on food industry sales (i.e. 23.2\% in 2016), on number of employees $(24.4 \%)$, and a number of enterprises $(25.1 \%)$. The problem is branch wages, employees are remunerated below the average wage (compared to CZ-NACE 10 Manufacture of food products) and there is a long time decline in the number of employees (Ministry of Agriculture, 2017). Competitiveness of this sector is quite low, it is a key issue of this branch and it is desirable to improve it. A factor that can contribute to their improvement can be subsidies. Therefore, the analysis dealt with businesses drawing subsidies to identify their role in improving bad branch situation.

An important instrument of the food industry are innovations and investment activities (Menrad, 2004). Investment subsidies are the main instrument of industrial policy for economically developed countries around the world (Skuras et al., 2006). These activities influence the growth of a firm with a cumulative effect and can be difficult to quantify (Geroski et al., 1997). Coad and Rao (2008) believe that no firm can survive without at least some innovation. According to Bernini and Pellegrini (2011), public subsidies are targeted at influencing the regional allocation of investment and employment in order to increase competitiveness, sustainable growth and create new jobs in low-income regions. The effect of investing on economic growth may be reflected in a long term horizon. Even in an uncertain market environment, there is a lag in the effects associated with the investments (Bloom and Van Reenen, 2002). 
Arkarhem et al. (2010) analysed the impact of investment grants on business performance. The companies that received the grants did not have better performance (measured by the return on equity) than non-supported. In most years, the subsidy recipients did not even hire more employees. Therefore, the results question the use of investment subsidies as a general policy tool to improve company's business performance. On the contrary, Wren (2005) reveals that these subsidies were successful in the creation of new job opportunities. According to Harris and Trainor (2005) investment aid reduces the closure of the processing businesses. Investments as a means of growth in company revenue were also evaluated by authors Geroski (2005) or Aghion and Howitt (1992). Cerqua and Pellegrini (2014) found the positive and statistically significant impact of subsidies on employment and turnover. According to Freel (2000), there is no significant difference in the revenues (profits) of supported and unsupported enterprises. However, the number of employees increased in the supported enterprises, but have a significantly lower level of profit.

According to Mroczek (2013), there was a significant recovery of investments and an increase in the value of fixed assets in the food industry in Poland. Investments in active parts of businesses (machinery and equipment) have significantly improved the performance of the industry. Skuras et al. (2006) dealt with the effect of capital subsidies on productivity growth in Greek food and beverage companies. The results of their research question the effectiveness of capital subsidies in increasing productivity.

Evaluation of Measure I. 1. 3 Adding value to agricultural and food products in the Czech business environment was conducted by Mezera and Špička (2013) and Mezera et al. (2014). Mezera and Špička (2013) point in their paper to the consolidation of the economic position of the subsidized enterprises. Aid has a positive impact on financial stability and increases productivity. Mezera et al. (2014) results have shown that funds aim at product innovation. Results from the questionnaire indicate the presence of macroeconomic, specifically environmental and administrative, problems that create limiting barriers for the innovation growth. The literature research shows diverse results, therefore raises the question how is the investment reflected in the business economics (economics of meat industry businesses in the Czech Republic) of Czech meat industry environment. The aim of the article is to quantify impacts of investment subsidies RDP 2007-2013, Measure I. 1. 3 Adding value to agricultural and food products in supported meat industry businesses. The measure followed the objective of improving the competitiveness of the agri-food sector, focusing on supporting the performance of processing enterprises, developing product sales, and developing innovation. The subsidies attempted to address a low share of production with higher added value, low labour productivity or a low degree of innovation. Previous programming period had been completed and a new CAP reform was defined. Therefore, it is appropriate to assess whether the subsidies have any contribution to the higher business performance of subsidized businesses.

\section{Methodology}

\subsection{Data}

The data used to process the impact analysis of subsidized enterprises' business economy were obtained from the Albertina database which lists companies and institutions and are administered by Bisnode. This allows us to gain complex reports on entities (data from financial statements). Companies were selected from the database according to 
CZ-NACE, Section C - Manufacturing industry, namely Section 10 - Manufacturing of Food Products, Branch 10.1 Meat processing and preserving of meat and production of meat products. Due to the impact assessment of the RDP for the entire programming period 2007-2013, only the enterprises with complete accounting data for the given period were selected. The data set was linked to the databases of reimbursed projects submitted by legal entities under measure I.1.3, provided by the Ministry of Agriculture (MoA). The database of supported enterprises including their accounting data was created.

In total 93 enterprises of branch 10.1 were supported, the accounting data was available to 81 enterprises of legal entities. In conclusion, $87 \%$ of supported meat industry enterprises have been analysed.

\subsection{Methods}

Impact assessment on the business economy was analysed using econometrics models, specifically panel data analysis (fixed effect models). According to Khandker et al. (2010), this quantitative method is suitable for evaluating the impact of public programs. The public support evaluation is the subject of this paper and it is the main reason, why this method was applied. Only the PSM (propensity score matching) method was used to evaluate the impact of subsidies in the Czech Republic by Mezera and Špička (2013), or on-line interview (Mezera et al., 2014). The econometric fixed effect model was applied in order to evaluate the impact of subsidies on the business economy of supported enterprises.

Impacts were evaluated in relation to the economy of the enterprises, respectively to financial-economic indicators. These indicators were selected based on literature research and their use for quantification of impacts studied by different authors. These are the indicators: number of employees, fixed assets, sales of own products and services, production consumption, added value, labour productivity, profit, debt ratio.

At first, model assumptions were tested. Adequacy of Fixed effect model (FEM) was validated by the Hausman test. The essence of the test is to verify that the random variable is correlated with the explanatory variables (Wooldridge, 2010). Autocorrelation of residuals was also tested by the Durbin-Watson test (Wooldridge, 2009). Heteroscedasticity of residues was tested using the Wald test of group heteroskedasticity. The existence of homoscedasticity ( $\mathrm{H} 0$ ) assumes that the values of the dependent variable (y) have the same variance of the random component across all values of the independent variables (x). Conversely, the existence of heteroscedasticity (H1) assumes that the variance of the random component differs across values of an independent variable (Baum, 2001). The Jarque-Bera test was used to test the residual normality (Jarque and Bera, 1980). The fixed effect model diagnosis includes a Chow test for various intercepts (Chow, 1960), which can be used to assess the statistical significance of individual effects, i.e. whether there are differences between enterprises in terms of the differential influence of systematic unobserved factors (quality of management, region, sales conditions, working environment, etc.). Because of the length of the paper it is not possible to specify the test more. For more details, please look mentioned literature.

Heteroscedasticity and autocorrelation (based on the above tests) were present in the estimated models, which may be a problem for statistical inference in each regression considered. Therefore, the robust Arellano estimation of the covariance matrix was chosen. Arellano's estimate of the covariance matrix looks like (Arellano, 2003): 


$$
\hat{\sum}_{A}=\left(X^{\prime} X\right)^{-1}\left(\sum_{i=1}^{N} X_{i}^{\prime} \hat{u}_{i} \hat{u}_{i}^{\prime} X_{i}\right)\left(X^{\prime} X\right)^{-1}
$$

where $X$ is the matrix of regressors, their values are centred around the first moment, $\hat{u}_{i}$ denotes the residual vector for the $\mathrm{i}$-th unit, and $\mathrm{N}$ is the number of cross-sectional units. A robust estimation of the covariance matrix was chosen in all cases, because the procedure that would preserve the estimation efficiency, was not available due to the data structure.

The Fixed Effect Model was used to analyse the dependence of the economic indicators, i.e. the number of employees (persons), fixed assets (thousands of CZK), sales (thousands of $\mathrm{CZK}$ ), production consumption (thousands of $\mathrm{CZK}$ ), added value (thousands $\mathrm{CZK}$ ), labour productivity (thousands of CZK), profit (thousands CZK) and debt ratio (in \%) on the amount of money received from Measure I. 1. 3 Adding value to agricultural and food products within the RDP 2007-2013 (in thousands CZK).

Panel regressions between economic indicators (i.e. dependent variables listed above) and investment grants (i.e. explanatory variables) were formulated. The model included a lagged variable in investment subsidies to determine whether subsidies have an immediate impact on the economy of the companies in the given year, or with a lag (one-year lag is considered).

In particular, the model is formulated as follows:

$$
y_{i t}=\alpha_{i}+\beta_{1} x_{1 i t}+\beta_{1} x_{1 i t-1}+\mu_{i}+v_{i t},
$$

where

$y_{i t} \quad$ represents one of the dependent variables;

$x_{1 i t}$ represents the amount of subsidies drawn by individual food businesses from the RDP, Axis I, Measure I. 1. 3 in the years 2007-2013;

$x_{1 i t-1}$ represents the amount of subsidies drawn by individual food businesses from RDP, Axis I, measure I.1.3 in the years 2007-2013. This is a lag variable of one year $(t-1)$.

The eight variables mentioned above are considered as explained variables. It explains how these variables change if there is a change in the subsidies by unit (one thousand CZK). All variables in the model enter as panel data, i.e. the variables were surveyed individually for each enterprise in individual years 2007 to 2013 . The subsidy variable enters the model as the only explanatory variable. Information on the use of subsidies was collected at company level in specific amounts (in the years when the company received a subsidy, its specific amount is stated. In the years when the enterprise did not draw subsidy, the value of the variable is zero) from the data provided by the Ministry of Agriculture.

Considering a total of eight dependent indicators, eight models were estimated. All modelling was done in the Gretl program.

\section{Results}

The following table 1 summarizes the results of the fixed effect model (parameter estimates), respectively impacts of RDP subsidies on selected economic indicators. Impacts at time, $\mathrm{t}$, but also lag effect of subsidies (one year) are mentioned. The 
parameter represents a change in the indicator when the amount of subsidy is changed (i.e. by a thousand crowns).

Table 1 | Estimation of FEM parameters, meat industry enterprises

\begin{tabular}{|l|c|c|c|c|c|c|c|c|}
\hline & $\begin{array}{c}\text { Number of } \\
\text { employees }\end{array}$ & Sales & $\begin{array}{c}\text { Production } \\
\text { consump- } \\
\text { tion }\end{array}$ & $\begin{array}{c}\text { Fixed } \\
\text { assets }\end{array}$ & Profit & $\begin{array}{c}\text { Labour } \\
\text { produc- } \\
\text { tivity }\end{array}$ & Debt ratio & $\begin{array}{c}\text { Value } \\
\text { added }\end{array}$ \\
\hline Constant & $147.528^{* * *}$ & $338249^{* * *}$ & $304506^{* * *}$ & $150610^{* * *}$ & -150.696 & $274.097^{* * * *}$ & $26.3956^{* * *}$ & $62486.8^{* * *}$ \\
\hline RDP t & $0.0028^{*}$ & 0.0311 & 0.4130 & $1.8219^{* *}$ & 1.6052 & 0.0029 & 0.0003 & -0.2329 \\
\hline RDP $t-1$ & 0.0023 & $2.1963^{*}$ & $2.7164^{* * *}$ & 0.3053 & 1.5159 & 0.0028 & $0.0004^{* *}$ & -0.0791 \\
\hline $\begin{array}{l}\text { Hausmann } \\
\text { test }\end{array}$ & {$[<0.0001]$} & {$[0.0013]$} & {$[0.0018]$} & {$[0.0157]$} & {$[0.0177]$} & {$[<0.0001]$} & {$[<0.0001]$} & {$[0.0013]$} \\
\hline $\begin{array}{l}\text { Wald test of } \\
\text { heteroske- } \\
\text { dasticity }\end{array}$ & {$[<0.0001]$} & {$[<0.0001]$} & {$[<0.0001]$} & {$[<0.0001]$} & {$[<0.0001]$} & {$[<0.0001]$} & {$[<0.0001]$} & {$[<0.0001]$} \\
\hline $\begin{array}{l}\text { Test of } \\
\text { normality }\end{array}$ & {$[<0.0001]$} & {$[<0.0001]$} & {$[<0.0001]$} & {$[<0.0001]$} & {$[<0.0001]$} & {$[<0.0001]$} & {$[<0.0001]$} & {$[<0.0001]$} \\
\hline Chow test & {$[<0.0001]$} & {$[<0.0001]$} & {$[<0.0001]$} & {$[<0.0001]$} & {$[0.9985]$} & {$[<0.0001]$} & {$[<0.0001]$} & {$[<0.0001]$} \\
\hline
\end{tabular}

Note: The value of the parameter is given, including $p$ value indicating the statistical significance of the parameter. This is indicated by stars, " $*$ " means that the parameter is significant at the significance level of $10 \%$, "** " at a significance level of $5 \%, "$ "***" at a significance level of $1 \%$. For the test model assumptions, only p-test values are listed in the table. Values are in thousands CZK, in case of the number of employees these are persons, debt ratio in \%.

Source: own processing according to data of the Ministry of Agriculture and Albertina

This work has shown an impact on the number of employees and the on the value of fixed assets for the subsidized enterprises. Grant programs should contribute to creating new jobs and reducing unemployment. Loss of employees is a problematic area in the food industry in the context of low wages and the labour intensiveness of some manufacturing branches. There is an an increase of 3 new workers with every million CZK of subsidy. This impact can be assessed as positive, given that the increase in the number of workers is a priority of the program. However, these employees were not effectively used, and other indicators did not grow. With a lagged effect of subsidies, the number of workers has not been further expanded and there has been no clear impact of higher labour utilization.

Investment subsidies are related to the growth of property assets of enterprises, as investments in new technologies, machinery, and buildings modernization. It can be assumed that their value is reflected in the growth of fixed assets. There has been an increase in these assets, however, no effective use has been demonstrated. Supported businesses displayed an increase in assets by 1.8219 thous. CZK with every million CZK of subsidy. This is a consequence of the expansion of the technical potential of the enterprises resulting from the nature of the investments in this branch. Companies primarily requested support for the purchase of packaging and labelling machines, refrigeration and freezing equipment, or for the redevelopment of buildings. They also benefited from financial support from the sub-measure (I. 1. 3. 2 Collaboration), in which they 
collaborated with research institutions to improve product quality or implementation of new procedures. However, the effective use of workers and property did not reflect other performance indicators in the year of drawing.

Subsidies should contribute to the improvement of the business performance, which should be reflected in the growth of revenues. There was a lagged impact on revenues for subsidized meat businesses. As a consequence of the implementation of the new investments supported by the subsidy program, the impact on production consumption should also be impaired, or the company should report savings on materials or energy. In the case of meat processors, there was an increase in production consumption rather than increase in sales. Supported firms increased their sales with the lagged effect in the next year by 2.1962 thous. CZK and their production consumption increased by 2.7164 thousand CZK. It is desirable that the growth of sales exceeds the growth of the production consumption, which in this case may be dampened by the impossibility of realizing its production on the market at the required prices, which would consider the new product characteristics.

Higher investment activity is also related to the use of liabilities, bank loans. The results show a lagged effect of subsidies on bank debt for the meat processing businesses. Every million crowns of subsidies will raise the debt by $0.3 \%$. The lagged effect can be caused by the fact that businesses first use their own resources, and then (in the coming years) they are complementary to bank loans, which is likely given that the SMEs prefer financing from their own resources.

Another problematic area within RDP subsidies, Axis I, is the low labour productivity which should be solved through this program. These supports should contribute to its growth in the food industry. Another specific area which the subsidies should improve is the low share of production with higher added value and insufficient product finalization. There was no impact on business added value.

Due to the expansion in funds in order to support this sector, economic effects can be considered as insufficient. In terms of performance, it would be desirable to achieve higher labour productivity or value added growth or higher degree of processing of products, which are problematic areas of the meat industry. Current investments have been made primarily for the purchase of technological equipment, not to improve the quality of the processing, which may be the main cause of no significant improvement in performance characteristics. Therefore, it is desirable that such subsidies be directed mainly to promote product quality or product processing.

\section{Discussion}

According to Davies and Kochhar (2002), the effectiveness of investment supports, in the context of country specifics, influences the relationship between processing practice and performance. Despite this diversity of investment support between countries, a concise discussion of the impacts of analysed indicators with foreign authors is made. However, the impacts demonstrated in the Czech environment are considered as conclusive.

The first analysed was the indicator number of employees. Results showed a positive impact, also like Cerqua and Pellegrini (2014). However, employment can also be reduced due to technology savings (Hall, 1994). According to Freel (2000), the growth of the number of employees is seen as the direct result of successful investments in the 
context of revenue growth and improvement in competitiveness. Our analysis has not fully confirmed the link between the growth in the number of employees and its contributed to improving competitiveness.

Investment activity is often associated with rising profits. According to Heunks (1998), profit growth does not have to occur immediately. Low profits may be associated with the cost of this investment, and the success of the implementation of the investment may not be apparent several years after implementation. For this reason, the article looked at the lagged effect of subsidies. The influence on profit was not verified on the selected sample. Freel (2000) found average negative effect on profit. A positive relationship was found by Wynarczyk and Thwaites (1997).

The objective of investment supports in the food industry was to revive investment activities that are considered as low in the food industry. As a result, there was an increase in the value of fixed assets. Mroczek (2013) or Bernini and Pellegrini (2011) studies also show the same effect.

Research in foreign literature also shows the difference in the impact on labour productivity. A positive relationship was shown, for example by Bernini and Pellegrini (2011). Negative, on the other hand, by Cesaratto and Stirani (1996).

In the Czech environment, the impact of RDP subsidies was analysed by authors Mezera and Špička (2013). According to their results, the economic position of the supported enterprises was strengthened. The subsidies have a positive impact on financial stability and increase in labour productivity. It states that the economic results are mitigated by higher depreciation due to investments in fixed assets. The statistically significant impact of subsidies on labour productivity and decline in profit due higher investment activity has not been demonstrated in this paper. Mezera et al. (2014) also dealt with evaluation of RDP. However, their survey was based on a questionnaire, so it is not possible to compare with the applied quantitative method.

The following text summarizes our findings:

- In subsidized enterprises there were an impact on the number of employees and on the value of fixed assets, but no effective use has been demonstrated.

- There was a lagged impact on revenues for subsidized meat businesses.

- The results show a lagged effect of subsidies on bank debt for the meat processing businesses.

- There was no impact on business added value and labour productivity.

\section{Conclusion}

The contribution lies in the quantification of subsidization impacts on the meat industry businesses performance and identifies whether there is a contribution to its improvement. The goal was fulfilled by applying fixed effects models. The impacts on selected economic indicators were examined. As a result, enterprises drawing subsidies in 20072013 showed an increase in the assets of the company, employees, and indebtedness. The sales growth had increased, however, it had grown less than production consumption.

In the view of the unfavourable meat industry economic situation, these impacts can be considered as less efficient to ensure the growth of business performance and 
better competitiveness. The growth of fixed assets of businesses have developed technical potential and innovated technologies for final product modifications (packaging, marking), etc. However, these resources have not been used efficiently enough. It may be an investment in equipment or property that brings other benefits than economic to the enterprise. An example of this is the food industry, where meeting standards is necessary (for example hygienic and environmental), complying with different standards, or using environmentally friendly technologies. It is possible to achieve effects that cannot be quantified unequivocally in the economy of enterprises (e.g. increased work safety, easier operation of machines, increasing product durability, limiting additives in products, but also customer satisfaction, etc.).

In terms of performance, it would be desirable to achieve higher labour productivity or value added growth, higher degree of processing of products, which are problematic areas of the meat industry.

\section{References}

Aghion, P., \& Howitt, P. (1992). A model of growth through creative destruction. Econometrica, $60(2), 323-351$.

Arellano, M. (2003). Panel Data Econometrics. Oxford: Oxford University Press.

Arkarhem, M., Daunfeldt, S. O., \& Quoreshi, S. (2010). Do regional investment grants improve firm performance? Evidence from Sweden. Working papers in economics, No. 04/09.

Baum, C. F. (2001). Residual diagnostics for cross-section time series regression models. The Stata Journal, 1(1), 101-104.

Bergstörm, F. (2000). Capital Subsidies and the Performance of Firms. Small Business Economics, 14(3), 183-93.

Bernini, C., \& Pellegrini, G. (2011). How are growth and productivity in private firms affected by public subsidy? Evidence from a regional policy. Regional Science and Urban Economics, 41(3), 253-265.

Bloom, N., \& Van Reenen, J. (2002). Patents. real options and firm performance. Economic Journal, 112(478), 97-116.

Chow, G .C. (1960). Test of Equality between Sets of Coefficients in Two Linear Regressions. Econometrica, 28(3), 591-605.

Cerqua, A., \& Pellegrini, G. (2014). Do subsidies to private capital boost firm's growth? A multiple regression discontinuity design approach. Journal of Public Economics, 109, 114-126.

Coad, A., \& Rao, R. (2008). Innovation and firm growth in high-tech sectors: A quantile regression approach. Research Policy, 37(4), 633-648.

Davies, A., \& Kochnar, A. (2002). Manufacturing best practice and performance studies: a critique. International Journal of Operations and Production Management, 22(3), 289-305.

Freel, M. S. (2000). Do small innovating firms outperform non-innovators? Small Business Economics, 14(3), 195-210.

Geroski, P. A. (2005). Understanding the implications of empirical work on corporate growth rates. Managerial and Decision Economics, 26(2), 129-138.

Geroski, P. A., Machin, J., \& Walters, C. F. (1997). Corporate growth and profitability. Journal of Industrial Economics, 45(2), 171-189.

Hall, P. (1994). Innovation. Economics and Evolution. Hemel Hempstead: Harvester Wheatsheaf. 
Harris, R., \& Trainor, M. (2005). Capital Subsidies and Their Impact on Total Factor Productivity: Firm-level Evidence from Northern Ireland. Journal of Regional Science, 45(1), 49-74.

Heunks, F. (1998). Innovation, Creativity and Success. Small Business Economics, 10(3), 263-272.

Jarque, C. M., \& Bera, A. K. (1980). Efficient tests for normality, homoscedasticity and serial independence of regression residuals. Economics Letters, 6(3), 255-259.

Khandker, S. R., Koolwal, G. B., \& Samad, H. A. (2010). Handbook on Impact Evaluation. Quantitative Methods and Practices. Washington DC: World Bank.

Menrad, K. (2004). Innovations in the food industry in Germany. Research Policy, 33(6-7), 845-878.

Mezera, J., \& Špička, J. (2013). Economic Effects of Investment Support of Adding Value to Food. Agris on-line Papers in Economics and Informatics, 5(1), 39-49.

Mezera, J., Němec, R., \& Špička, J. (2014). Support of strengthening the cooperation and efficiency factors accelerating innovation processes in the food industry. Agricultural Economics, 60(7), 295-300.

Ministry of the Agriculture of Czech Republic (2017). Panorama of food industry 2016. Prague: Ministry of the Agriculture of Czech Republic.

Mroczek, R. (2013). Investment. assets of enterprises and productivity of the polish food industry. In Hradec Economic Days 2013 - International Conference (pp. 258-265). Hradec Králové: University of Hradec Králové.

Skuras, D., Tsekouras, K., Dimara, E., \& Tzelepis, D. (2006). The Effects of Regional Capital Subsidies on Productivity Growth: A Case Study of the Greek Food and Beverage Manufacturing Industry. Journal of Regional Science, 46(2), 355-381.

Wooldridge, J. M. (2009). Introductory Econometrics: A Modern Approach. USA: South-Western Cangage Learning.

Wooldridge, J. M. (2010). Econometric Analysis of Cross Section and Panel Data. London: MIT Press.

Wren, C. (2005). Regional Grants. Are they Worth it? Fiscal Studies, 26(2), 245-75.

Wynarczyk, P., \& Thwaites, A. (1997). The Economic Performance. Survival and Non-Survival of Innovative Small Firms. In: Oakey. R., \& Mukhtar. S. New Technology Based Firms in the 1990s. London: Paul Chapman.

\section{Author}

\section{Zdeňka Náglová}

Researcher

Institute of agricultural economics and information, Section Research

Department of Economics of Agriculture and Food Industry

Prague, Czech Republic

naglova.zdenka@uzei.cz 